\title{
Decision Support System For Determining Power Loss And Refurbishability Of Failed Automotive Petrol Engine Block And Crankshaft
}

BASIL OLUFEMI AKINNULI

Federal University of Technology Akure

OLADELE AWOPETU

Federal University of Technology Akure

OLUWASEUN OLUWAGBEMIGA OJO ( $\square$ ojo.oluwaseun@adelekeuniversity.edu.ng )

Adeleke University https://orcid.org/0000-0002-8678-092X

Original Article

Keywords: Wear, Performance of the Vehicle, Power loss, Economy, Torque, Cylinder engines, Computer software, C-sharp

Posted Date: June 24th, 2021

DOI: https://doi.org/10.21203/rs.3.rs-585333/v1

License: (c) (i) This work is licensed under a Creative Commons Attribution 4.0 International License. Read Full License 


\section{Abstract}

The crankshaft and engine block of automobile wear or fail after certain years of usage. The cause of failure is a contributing factor to the power loss of the engine. Power loss reduces the performance of the vehicle. Due to the economic situation in Nigeria, the cost of buying new engines is usually high and some used engines have problems that are latent. Pre-test engine analysis was carried out and torque of each selected engine was measured with a dynamometer to know the speed of the worn engine.

Disassembly of four (4) cylinder engines namely; Toyota, Nissan, Mitsubishi, and Mazda were carried out and the affected failed parts, namely; main bearing, crankpin journal, and bore cylinder diameter were determined and the level of their wear as well as power losses ascertained using measuring instruments. For easy computation and analysis, a computer software using C-sharp programming language was developed to determine the power loss and predicting machining level of refurbish-ability and tested for performance evaluation. The model and its developed software are decision support tools for any automotive industry where maintenance and management of engines for improved performance and efficiency of operation is the focus.

\section{Full Text}

This preprint is available for download as a PDF. 